\title{
The Ready to Drink Tea Element of Promotion, Place \& Price. A Case Study@pucukharumid
}

\author{
Yuli Harwani Janfry Sihite* \\ Department of Management, Universitas Mercu Buana, Indonesia
}

\begin{abstract}
This research conducted to explore the attributes of marketing communication@pucukharumid from July to December 2017. The Exploratory Factor Analysis conducted with the Provalis Software that could simplify the unstructured tweet data set into insights. There is 1083 tweet that analyzed for further analysis. The results show that@pucukharumid promoting the varieties of @pucukharumid product with a variety of youth and family activities. The research concluded that@pucukharumid are targeting the youth and also related the activities of food and drinking with@pucukharumid.
\end{abstract}

Keywords: @pucukharumid, Marketing Communication, Unstructured Dataset

DOI: $10.7176 / \mathrm{EJBM} / 11-24-09$

Publication date: August $31^{\text {st }} 2019$

\section{Research Background}

The competition for ready to drink tea in Indonesia is proliferating. Companies competing to fulfill the needs of the consumer, related to the attributes of the ready to drink tea and deliver a combination of attributes relevant to convince the consumer to buy the ready to drink tea (Euromonitor, 2018b).

Indonesia competition for ready to drink tea is intense, The Gelas had the majority market share, followed with The Pucuk Harum, and also there are The Sosro, Frestea that also have a significant market share (Euromonitor, 2018c). Most of the brand market share is increasing, but The Sosro. This phenomenon shows that the brand is trying to reach more consumer base in the industry.

Each brand should have a distinctive strategy to promote the product and leverage the product position in the minds of the consumers (Nugroho, 2018c). Since every product is delivering a proposition, therefore it is essential to analyze the product proposition for the brand.

The product proposition is the promise delivered from the product to the consumers. This promise delivered via the online or offline marketing communication channel; therefore, to get an insight to relate to the marketing communications strategy, we could observe and analyze the brand marketing communication channel.

One of the brands that have reached a significant improvement is Teh Pucuk Harum that has $11.1 \%$ of market share. Furthermore, Pucuk Harum is the youngest brand in the category. There is some relevant marketing communication attribute that delivered to the targeted market. Therefore this research explores the attributes from@pucukharumid from July to December 2017.

\section{Theoretical Review}

There are many attributes for the product, such as price and an essential attribute for consumers (Amornpetchkul, 2016) (Ferrarezi, Minim, dos Santos, \& Monteiro, 2013) (Sihite, Harun, \& Nugroho, 2015). Price is the cost that the consumer should sacrifice to earn the goods and the services. Therefore what the consumer sacrifice should give the consumer benefit.

Nevertheless, before the consumer consuming the product, or buying the product, the consumer should be convinced that they will purchase the product. Therefore there are attributes which are the benefits of purchasing the product that should be received by the targeted consumers.

The quality of the product, the features, and benefits, which are the proposition delivered via the marketing communication channel. The ready to drink tea have product quality such as the flavor, the taste, the ingredients that are the determinant of the consumer to purchase the product.

The variety of ready to drink tea packaging is also one of the propositions to targeted consumers. There are PET bottles, and also plastic wall containers, both of the choices reflect the attributes that the consumer prefer (Euromonitor, 2018a).

\section{Research Method}

@pucukharumid is a twitter for ready to drink tea The Pucuk Harum, therefore@pucukharumid selected as the growing ready to drink tea in Indonesia. Data extracted from the twitter channel @pucukharumid for the period July to December 2017. There are 1083 tweet processed for further analysis.

The data processing start with data preparation, excluding the double posted data (Figure 1). Furthermore, the data analysis conducted after the data cleaned. The analysis with the Provalis research software will expose the insight from 1083 tweet dataset. 


\begin{tabular}{|c|c|c|c|c|}
\hline $\begin{array}{c}\text { Data Extraction } \\
\text { @pucukharumid }\end{array}$ & $\rightarrow$ Data Preparation & $\begin{array}{c}\text { Exploratory Factor } \\
\text { Analysis }\end{array}$ & Findings \& Discussion \\
\cline { 1 - 2 } 1083 Dataset & $\rightarrow \begin{array}{c}1058 \text { Tweet \& } \\
\text { 25 ReTweet }\end{array}$ & Product, Price, \\
Promotion \& Place
\end{tabular}

Figure 1. Research Process

The tweet dataset analyzed with the exploratory factor analysis technique to expose the relationship within the tweet dataset to find the insight within the data (Wijanto, 2008) (Hair, Anderson, Tatham, \& William, 1998). The exploratory factor analysis conducted since there is a lack of theory related to the ready to drink tea.

The exploratory factor analysis conducted for the hospitality (Nugroho, 2018b) (Nugroho, Sihite, \& Harwani, 2019), coffee shop (Harwani \& Sihite, 2019), kitchen application (Sihite, 2019b), online transportation (Sihite, 2019a), education (Nugroho \& Sihite, 2015a) (Nugroho \& Sihite, 2015b), National Tourism Organization (Sihite \& Nugroho, 2018) (Nugroho \& Sihite, 2018) (Nugroho, 2017), airline (Sihite Nugroho, 2015) (Nugroho \& Sihite, 2015), banking (Nugroho \& Sihite, 2016) (Nugroho, 2018a).

The results of the exploratory factor analysis are themes that could be interpreted after the complexity of the data reduced to a specific dimension (Campbell, Pitt, Parent, \& Berthon, 2011). The exploratory factor analysis utilized the Provalis Research Software consists of the QDA Miner to identify the relationship between keywords (Silver \& Lewins, 2014).

\section{Results and Discussion}

@pucukharumid is a new player in the market; therefore, @pucukharumid need to be accepted in the market by introducing@pucukharumid to the targeted consumer. The results show that @pucukharumid developing a more extended relating to the youth. This investment strategy for introducing the young market conducted by delivering marketing communication to the youth through music and sports activities, furthermore there are also family activities arranged to the targeted market.

The exploratory factor analysis for the attribute delivered by@pucukharumid show that @pucukharumid tweeting variety of product. Introducing the Jumbo Tea product, this is a part of the 7P marketing mix which is product knowledge.

Furthermore, marketing communication also combining the ready to drink tea as a complementary product for the food. This strategy by promoting a bundle package of CFC gets. This package consists of Teh Pucuk Harum, chicken and also a CD song.

Strategy to introduce@pucukharumid in the restaurant that is well known like CFC is a strategy to increase the level of @pucukharumid in line with the class of the restaurant, since they are both paired in the eyes of the consumers. This kind of strategy is useful to the targeted consumer and also to increase the @pucukharumid leverage in the market.

@pucukharumid is also developing marketing communication to associate the activity of drinking tea with eating food. Promoting the morning breakfast with@pucukharumid, and whatever the food you eat, the drink is @ pucukharumid. Furthermore, @ pucukharumid is also developing an association as complimentary drinking when you eat cookies.

Moreover, association to develop@pucukharumid also conducted by developing an association of the family activities with@pucukharumid. The togetherness moment is the focus that is delivered by @ pucukharumid to increase the excitement of the activity with the family, having a snack with the family these promotion delivered by @pucukharumid.

The togetherness moment also developed in the activities at the fasting month. @pucukharumid deliver the tweet to open the fasting together with the family with drinking@pucukharumid. Support the netizen to have the right moment of fasting. @pucukharumid also delivering special attention to the moment in the fasting month, there is a statement relating to the moment of eating Takjil when you are opening the fast with the family.

This crucial point in the fasting month delivers by @pucukharumid as a crucial moment that the consumer should have with@pucukharumid. Finally, and end of the fasting month, which is the Eidul Fitri. @ pucukharumid is doing a remarkable promotion by supporting the moment of looking for the Mudik ticket with drinking@pucukharumid. After the moment of buying the mudik ticket is over, then the @pucukharumid promoting the activity of the Mudik with the family by the companion of @pucukharumid.

@pucukharumid is also investing the activity to the production target market in the long term. The target market is the student that have many activities and start to gain the purchasing power.@pucukharumid developing a good relationship with the target market by crowdsourcing the activities that the student do, furthermore@pucukharumid helping the students to find the promotion budget to support the activities. @ pucukharumid asked for the activities proposed, and they will choose which of the activity that will be supported by@pucukharumid. 
School roadshow also conducted to promote the Pucukcooljam activity endorsement in school. The Pucukcooljam is an event to perform in school, to support the band extracurricular to perform in their school. The promotion to the youth that like music associated with@pucukharumid.

Another activity that they promote is the basketball league. The basketball league also an activity that relates to the youth, and the perception of the basketball is cool. The activity to support the basketball will promote@pucukharumid in the youth community and make@pucukharumid exists in the community.

Finally, there is also an activity that @pucukharumid support, which is the JakCloth that is an expo with a musical concert. The JakCloth also interesting for the youth, since the youth are up to date with fashion, and also the JakCloth is one of the expo innovation that unites the concert music with the design and clothes expo.

The existence of@pucukharumid in the community will increase the @pucukharumid visibility toward the target market. Furthermore, the targeted market will see@pucukharumid as part of their group, a brand that supports the youth. Therefore @pucukharumid earn good sympathy from the target market.

The dendogram from@pucukharumid exploratory factor analysis for the period July to December 2017 expose several themes. The themes colored in red show the same discussion, delivering that Teh Pucuk Harum is suitable to accompany your everyday activities, the vacation, and also the enjoyment when you were eating.

In this tweet category, the enjoyment of Teh Pucuk Harum start from the sweetness, and it didn't stick in your neck, such as the Twitter@pucukharumid "guys, in this holiday it is very good that we are having a culinary vacation. Let's try the dim sum. Where is your favorite dim sum restaurant with your a boy? So if you want to keep cool and fresh eating dim sum, you should be accompanied with the sweetness of Teh Pucuk Harum that have a day is and also it didn't make you stuck in the neck. The bottom line in this group Teh Pucuk Harum is proposing the consumer the enjoyment of Teh Pucuk Harum drink.

In the next group of the tweet that colored in blue, there are events that Teh Pucuk Harum arranges; one of the events arranged is Pucuk Cool Truck. Pucuk Cool Truck is a competition of musical band for the senior high school student. The participant that is participating in the event has several benefits from Teh Pucuk Harum, which are a cash price, recording, and also video clip shooting with their favorite band. Furthermore, the winner also got the opportunity to perform with recognizing artists like Julian Jacob and rocket rockers.

There is also a tweet that promoting promotion cooperation between The Pucuk Harum and the other corporation; one of the examples is the promotion of Teh Pucuk Harum and Gokana Ramen. The promotion that they deliver is Super Mantap, @pucukharumid promoting value for money food with varieties of choices with a variety of food choices and Teh Pucuk Harum, November 12, 2017.@pucukharumid also using promotion activity to introduce their product to the community.

On 16 November 2017, @pucukharumid discussing that Teh Pucuk Harum is a suitable drink to release the thirst and also the tiredness after a day-long activity. This tweet came to convince the consumers and also the public that Teh Pucuk Harum has this enjoyment and good quality beverages for the community. @ pucukharumid also delivering a promotion content such as a promo to buy Teh Pucuk Harum $350 \mathrm{~mL}$ for only rp 4800, the Indomaret promo for the period 26 July until 8 August 2017 for one bottle of Teh Pucuk Harum regular $500 \mathrm{~mL}$ for only $\mathrm{rp} 3800$. They are also promoting with a company that is located in some mall. Furthermore, they are only delivering the promotion of @pucukharumid content, but also there is much information from the website.

On 6 October 2017, there is a tweet delivering a quotation from Gina crome about the benefit of a routine's activities in sport. In the quotation, the benefit will be gained from a routine exercise will help you to counter tiredness, improve the quality of sleeping, and to control the level of stress. This content is giving a benefit to the readers and also improve their knowledge for Sport, and also developing a suggestion about the importance of sports in term of the benefit that they could receive. It is not only information, but they also post some quizzes deliver to the consumer. This activities of developing relational communication, and engagement with the netizen, that will be responded by the followers. One example of the quiz is the question if Teh Pucuk Harum jumbo for 1.5L distributed into some bottle for $50 \mathrm{~mL}$, how many glasses would it be?

This quiz responded by some followers, one of them is @oktaberliana that said correct guesses by replying that there are 30 glass. Teh Pucuk Harum also working together with some of the artists for co-promotion. Some of the tweet state that let's buy Teh Pucuk Harum in CFC and get the Rafathar CD! StaycoolNfresh. This promotion is a cooperation between Teh Pucuk Harum and CFC.

Teh Pucuk Harum also performing some events that they sponsored, like the @soundrenaline2017. This event arranges in 9 to 10 September 2017 in Bali GWK, and some recognize artist performing in the event. There are Sheila on 7, Tulus, Andien, Kotak, Payung Teduh. In this event, Teh Pucuk Harum opening booth, therefore, the visitor could come to the booth and also buying their product. @pucukharumid also delivering information related to cooperation. One of the account is asking an information, @enggale. Hi friend. For cooperation proposal, you can send the proposal to PT Mayora Indah, Jalan Daan Mogot Km 18, Kalideres, JakBar. UP marketing beverages. @pucukharumid also delivering information related to the quiz and also the challenge for the followers with interesting prizes. One of them is the tweet posted on August 3, 2017, where 
@pucukharumid asking for challenges to capture a video and information related to the quiz prizes which is the GIAS event ticket.

GIAS is a big automotive expo in ice BSD. GIAS Gaikindo Indonesia International Auto Show. In this event Teh Pucuk Harum also becoming the official ready to drink tea. There is so many enthusiastic netizen in the twitter that following the quiz, we could see from the numbers of respond that answering the post. For the netizen that participates in the quiz, when you are sending an answer, you should also tag four of your friend. There are 20 winners that are going to be chosen, but the winner in the quiz is only one, and the winner is @surya_sch.

This activity is a tool for promotion for Teh Pucuk Harum; therefore, there is more community more people know the product and also the twitter account. There are more accounts that follow the@pucukharumid, . Therefore they will engage and participate in the quiz info that @pucukharumid create.@pucukharumid also arrange a promo on a big national day like the Indonesian independence. In the independence day, @pucukharumid cooperate with some company like@RiceBowl_Indo,@Wendysindo. Promo proposition in the rice bowl restaurant is an independent promo. The promotion offer the customer only pays the vegetable. In this promo, the consumer only has to pay the vegetable and will have a bowl of free rice and also Teh Pucuk Harum. Moreover, in Wendys, the promo is six fried chicken +3 rice +3 Teh Pucuk Harum from the original price for Rp 120,000 to $\operatorname{Rp} 70,000$ s.

Furthermore, there is also@pucukharumid posting that delivers information that they got the awards from @swamediainc as the first Indonesian champion for original brand 2017 for the category package ready to drink tea. This is an achievement for Teh Pucuk Harum company, and they are exposing the achievement to the community that they have a good quality product. Not only that, but they also got the best stand-in Gambir for PRJ 2017.

\section{Conclusion}

@ pucukharumid are getting the youth and the family. Therefore @ pucukharumid engage with the activity and event that relate to the youth and the family. @pucukharumid focus on associating the product to the food that has a good quality, a well-known restaurant.

This activity is an effort to associate that @pucukharumid are part of the youth, a part of the Muslim consumers that experience the fasting month, a part of the sport activity, a part of the musical event, and also a part of daily activities of the Indonesian people that start the day with the breakfast, having cookies in leisure time, and more activities related to the Mudik and Lebaran.

Finally, @pucukharumid developed the association of lively, energetic like the youth and also a fresh brand. This long-term marketing communication investment that focuses on the youth will earn more consumer in the future since the youth will remember and have sympathy for @pucukharumid. Therefore in the future, @ pucukharumid will earn more consumers that have a good purchasing power and also independent in the decision-making process.

\section{References}

Amornpetchkul, T. (2016). Ichitan Group and the Price War in Thailand's Ready-to-Drink Tea Market. Journal of the International Academy for Case Studies, 22(3), 4.

Campbell, C., Pitt, L. F., Parent, M., \& Berthon, P. (2011). Tracking Back-Talk in Consumer-Generated Advertising: An Analysis of Two Interpretative Approaches. Journal of advertising research, 51(1), 224. doi:10.2501/jar-51-1-224-238

Euromonitor. (2018a). RTD Tea in Indonesia Analysis. Retrieved from

Euromonitor. (2018b). RTD Tea in Indonesia Analysis.

Euromonitor. (2018c). Tea_in_Indonesia_Analysis.

Ferrarezi, A., Minim, V. P., dos Santos, K. M., \& Monteiro, M. (2013). Consumer attitude towards purchasing intent for ready to drink orange juice and nectar. Nutrition \& Food Science, 43(4), 304-312.

Hair, J. F., Anderson, R. E., Tatham, R. L., \& William, C. (1998). Multivariate data analysis.

Harwani, Y., \& Sihite, J. (2019). The Marketing Mix Element of the Coffee Shop. A Case Study (a) CoffeeBeanIndo. European Journal of Business and Management, 11(18), 169-174. doi:10.7176/EJBM/11-18-20

Nugroho, A. (2017). ASEAN Tourism Marketing Communication Attribute: An Exploratory Research at Goaseantv. European Research Studies Journal, XX(3).

Nugroho, A. (2018a). Analisis Faktor Eksploratori Layanan@syariahmandiri. Jurnal Ekonomi, XXIII(3), 376388.

Nugroho, A. (2018b). The Hospitality Marketing Communication Attribute. A Case Study@hrhbali (Hard Rock Hotel Bali). Journal of Marketing and Consumer Research, 50.

Nugroho, A. (2018c). The Role of Price in Deciding to Purchase Ready-to-Drink Tea. Jurnal Manajemen, 
XXII(03), 380-394.

Nugroho, A., \& Sihite, J. (2015a). Is It A Relational Marketing Strategy? Cluster Analysis (a) Universitasmercubuanajakarta Facebook Post and Comment. Manajemen MIX, V(2).

Nugroho, A., \& Sihite, J. (2015b). Is It Traditional or Contemporary Marketing Strategy? A Textual Cluster Analysis@MercuBuana_Reg. Mediterranean Journal of Social Sciences, VI(5).

Nugroho, A., \& Sihite, J. (2015). Tweeting And Retweeting Tourism And Airline Service Attributes. Thomson Reuter Indexed Proceeding. International Geographical Union \& Lombok International Conference. University Mataram.

Nugroho, A., \& Sihite, J. (2016). Exploratory Factor Analysis Syariahmandiri and Bankmandiri Service Attributes 2015. . The Social Sciences, 11, 4896-4901.

Nugroho, A., \& Sihite, J. (2018). ASEAN Tourism Destination: A Strategic Plan. European Research Studies Journal, 21(3), 293-298.

Nugroho, A., Sihite, J., \& Harwani, Y. (2019). The Promotion, Product and the People of Luxurious Hotel: A Case Study@hrhbali 2018. Journal of Tourism, Hospitality and Sports, 41, 73-78. doi:10.7176/JTHS/41-01

Sihite, J. (2019a). The Online Transportation Marketing Mix CoCreation: A Case Study@gojekindonesia. Journal of Marketing and Consumer Research, 57, 44-50. doi:10.7176/JMCR/57-05

Sihite, J. (2019b). The Promotion and Process Attribute for the Kitchen Appliance. A Case Study @ KitchenAid Indo. European Journal of Business and Management, 11(18), 164-168. doi:10.7176/EJBM/11-18-19

Sihite, J., Harun, T. W., \& Nugroho, A. (2015). The Low Cost Airline Consumer Price Sensitivity. An Investigation on The Mediating Role of Promotion and Trust in Brand. International Research Journal of Business Studies, VII(3).

Sihite, J., \& Nugroho, A. (2018). Exploring the Indonesian Tourism Destination via Indonesia.Travel@indtravel. Silver, C., \& Lewins, A. (2014). Using software in qualitative research: a step-by-step guide.

Wijanto, S. H. (2008). Structural Equation Modeling dengan LISREL 8.8: Konsep dan Tutorial. 